\title{
PENDIDIKAN ISLAM HUMANIS DAN INKLUSIF
}

\section{Abdul Azis}

(Dosen Fakultas Ushuluddin, Adab dan Dakwah IAIN Kendari)

\begin{abstract}
Abstrak: Landasan pendidikan dalam Islam (epistemology pendidikan Islam) adalah Al Quran dan Al Hadits, al-Quran telah banyak membimbing dan mengarahkan umat manusia kaitannya dengan tarbiyah insania, konsep yang ditawarkan al-Quran telah diperaktekkan oleh Nabi Muhammad Saw. dan pendidikan dalam Islam menawarkan konsep rahmat lil'alamin bagi semua mahluk manusia terbuka, tanpa ada pengecualian dan manusiawi sesuai kodratnya. begitu juga dengan binatang konsep ini tidak mendikatomi golongan satu dengan yang lainnya.
\end{abstract}

Kata Kunci: Pendidikan, humanis dan inklusif 


\section{Pendahuluan}

Dengan memahami makna agama yang diyakini, yaitu Islam, maka sesorang muslim dapat memahami bahwa ia adalah agama yang mendambakan perdamaian. Cukup dengan mendengar ucapan yang dianjurkan untuk diucapkan dalam setiap pertemuan, yakni: assalamu'alaikum, seseorang dapat mengingat bahwa kedamaian yang didambakan bukan hanya untuk dirinya sendiri. Akan tetapi untuk pihak yang lain juga (M. Quraish Shihab, 1996: 378).

Maka prinsip perdamaian adalah sebagai salah satu ciri utama agama Islam. Ia lahir dari ajarannya tentang Allah, alam semesta, dan manusia. Karena Islam sebagai agama, tidak hanya merupakan doktrin peribadatan semata. Akan tetapi, lebih dari itu Islam merupakan way of life yang mampu menciptakan nilai-nilai kemanusiaan yang sesungguhnya.

Dalam al-Qur'an surat al-Anbiya' (21) ayat 107 dinyatakan bahwa Islam adalah agama yang membawa rahmat bagi semesta alam. Dengan kata lain, kapan pun dan di mana pun Islam berada, harus memberikan garansi bagi keselamatan dan kedamaian umat manusia di sekelilingnya. Bukan merupakan ancaman, apalagi enemy.

Prinsip al-Qur'an ini dilandasi atas penghargaan Islam terhadap kemanusiaan universal, karena pada prinsipnya Islam merupakan agama yang universal (Harun Nasution, 1995: 34, Nurcholish Madjid, 2000: 425).

Namun, prinsip al-Qur'an ini dalam tataran pembumiannya telah mengalami image yang sebaliknya. Islam sebagai sebuah agama, sering dituding sebagai sumber konflik yang bernuansa agama. Mengapa tindakan kekerasan [teror atau pengrusakan] terhadap kelompok yang secara ideologi berbeda selalu menggunakan dalil-dalil normatif agama untuk membenarkan bahwa tindakan kekerasan yang mereka lakukan secara ilmiah adalah benar? Mengapa terdapat kelompok keagamaan yang menampilkan wajah keberagamaan yang keras, atoleran, tertutup, selalu menyakini pandangan-pandangannya sebagai suatu yang paling benar dan keyakinan di luar kelompoknya adalah salah? Mengapa masih saja terjadi konflik horizontal antar komunitas yang mengatasnamakan agama seperti di Ambon, Poso dan seterusnya? Mengapa pekik-pekik yang pada awalnya dimaksudkan untuk mengagungkan Allah kemudian menjadi semacam alat untuk membantai dan menghakimi? Sehingga "Allahu Akbar" dan "la Ilaaha illa Allah" tidak lagi bermakna kebesaran Allah melainkan berarti "merobohkan pagar-pagar, menyerang tempat ibadah sesama Muslim, menyerang tempat-tempat maksiat dan sejenisnya"? Mengapa teks-teks agama begitu mudah dijadikan justifikasi tindakan kekerasan? Dan 
sederet pertanyaan-pertanyaan yang sempat membuat "wajah Islam" yang misi dasarnya ramah dan damai "berganti wajah" sebagai agama yang seram dan menakutkan.

Belakangan hari ini "wajah Islam" yang rahmatan lil'alamin kembali tercoreng. Pada tanggal 6 Februari 2011 sekelompok orang yang "mengaku Muslim" menyerang penganut Ahmadiyah di desa Cikeusik Pandeglang Banten sehingga menewaskan 3 orang penganut Ahmadiyah. Peristiwa lain pada tanggal 7 Februari 2011 dua kelompok organisasi Islam membakar beberapa Gereja di Kabupaten Temanggung. Dua peristiwa ini benar-benar telah mencoreng nama baik Islam sebagai agama rahmatan lil'alamin.

Persoalan-persoalan di atas itu apakah disebabkan kita sebagai umat Islam tidak mampu menangkap pesan agung nan luhur tentang nilai-nilai kemanusiaan dan perdamaian. Seperti yang terungkap dalam al-Qur'an surat al-Anbiya' (21) ayat 107 dinyatakan bahwa Islam adalah agama yang membawa rahmat bagi semesta alam.

Untuk menjawab kegelisahan akademik di atas, maka dalam tulisan ini penulis mencoba mengeksplorasi Qs. al-Anbiya' (21) ayat 107. Hal ini dilakukan agar supaya tidak lagi terjadi kesalahan atau distorsi dalam memahami teks-teks ayat suci al-Qur'an dan mencoba menampilkan kembali "wajah Islam” yang damai dan toleran.

\section{Islam Rahmatan lil 'Alamin}

Pernyataan Paradigma Islam: Rahmatan lil'Alamin merupakan sebuah kesimpulan dari firman Allah SWT QS. al-Anbiya' (21) ayat 107 sebagai berikut:

$$
\text { وما ارسلنا لك الا رحمة للعا لمين }
$$

Dan tidaklah Kami mengutusmu (wahai Muhammad), melainkan (menjadi) rahmat bagi semesta alam (QS. alAnbiya'/21: 107).

Ahmad Mushthafa al-Maraghi dalam Tafsir al-Maraghi menyatakan bahwa Rasulullah Saw., diutus dengan membawa ajaran yang mengandung kemaslahatan di dunia dan akhirat. Hanya saja orang kafir tidak mau memanfaatkannya dan berpaling darinya akibat tabiatnya yang telah rusak, tidak menerima rahmat ini dan mensyukuri nikmat ini, sehingga tidak merasakan kebahagiaan dalam urusan agama maupun dunia (Ahmad Musthofha al-Maraghi, 1993: 131).

Tim Tafsir UII dalam Al-Qur'an dan Tafsirnya mengungkapkan bahwa orang-orang yang beriman dan mengikuti petunjuk agama itu akan memperoleh rahmat dari Allah berupa rizki dan karunia di dunia 
dan akhirat nanti mereka akan memperoleh rahmat berupa surga yang disediakan oleh Allah bagi mereka. Sedangkan orang-orang yang tidak beriman, akan memperoleh rahmat pula, karena dengan cara yang tidak langsung mereka mengikuti sebagian ajaran-ajaran agama itu, sehingga mereka memperoleh kebahagiaan hidup di dunia (Tim Tafsir UII, 1995: 339).

Teungku Muhammad Hasbi ash-Shiddieqy dalam Tafsir alQur'anul Majid an-Nuur menafsirkan: Kami tidak mengutus kamu, hai Muhammad, untuk membawa agama yang sempurna, melainkan sebagai rahmat bagi segenap manusia dan sebagai petunjuk bagi mereka dalam semua jenis urusan di dunia dan akhirat.

Lebih lanjut Hasbi ash-Shiddieqy mengungkapkan bahwa umat Muhammad Saw., yang mengikutinya akan memperoleh rahmat dari agama ini secara langsung, sedangkan umat-umat lain yang tidak mengikutinya juga memperoleh rahmat agama ini, walaupun dengan cara yang tidak langsung. Nabi Muhammad Saw.,lah yang pertamatama menanamkan benih-benih demokrasi di dunia. Beliaulah yang mengawali pemberian pertolongan kepada orang-orang yang lemah, membantu orang-orang yang teraniaya, mengakui hak orang fakir, dan menyamakan pengikutnya dengan pengikut orang lain (Teungku Muhammad Hasbi ash-Shiddieqy, 2000: 2652).

Sayyid Quthb dalam Tafsir fi Zhilalil Qur'an menafsirkan risalah Muhammad Saw., merupakan rahmat bagi seluruh manusia dan bahwasanya nabi Muhammad Saw., di utus sebagai rahmat bagi seluruh alam semesta, baik yang beriman kepadanya maupun yang tidak beriman kepadanya secara bersama-sama. Sesungguhnya naungan rahmat itu akan terus dibentangkan bagi orang yang mau berlindung di bawah naungannya (Sayyid Quthb, 2004: 92).

Hamka dalam Tafsir al-Azhar menafsirkan risalah yang dibawa nabi Muhammad Saw., ini selain membawa rahmat untuk kaumnya, mengeluarkan mereka dari lingkungan sempit hidup berkabilah menjadi suatu bangsa yang besar yang berperadaban, dia pun menjadi rahmat bagi seluruh isi alam (Hamka, 2001: 123).

M. Quraish Shihab dalam Tafsir al-Misbah-nya menyatakan bahwa redaksi Qs. al-Anbiya' (21) ayat 107 itu sangat singkat, tetapi ia mengandung makna yang sangat luas. Hanya dengan 5 kata yang terdiri dari 25 huruf termasuk huruf penghubung yang terletak pada awalnya ayat ini menyebut 4 hal pokok, yaitu: (1) Rasul/utusan Allah dalam hal ini Nabi Muhammad Saw., (2) yang mengutus beliau dalam hal ini Allah SWT. (3) yang diutus kepada mereka (al-'alamiin). (4) risalah, yang kesemuanya mengisyaratkan sifat-sifatnya, yakni rahmat yang sifatnya sangat besar sebagaimana dipahami dari bentuk nakirah dari 
kata tersebut. Ditambah lagi dengan menggambarkan ketercakupan sasaran dalam semua waktu dan tempat.

Rasulullah Saw., adalah rahmat bukan saja kedatangan beliau membawa ajaran, tetapi sosok dan kepribadian beliau adalah rahmat yang dianugerahkan Allah SWT., kepada beliau. Ayat ini tidak menyatakan bahwa: "Kami tidak mengutus engkau (hai Muhammad) untuk membawa rahmat, tetapi sebagai rahmat atau menjadi rahmat bagi seluruh alam" (M. Quraish Shihab, 2006: 519).

Dari beberapa uraian pendapat ahli tafsir di atas, dapat penulis simpulkan bahwa nabi Muhammad Saw., merupakan rahmat bagi seluruh umat manusia, baik yang beriman kepadanya maupun yang tidak beriman dan bahwasanya nabi Muhammad Saw., itu di utus sebagai rahmat bagi seluruh alam semesta.

Tidak ditemukan dalam al-Qur'an seorang pun yang dijuluki dengan rahmat, kecuali Rasulullah Muhammad Saw., dan tidak juga satu makhluk yang disifati dengan sifat Allah ar-Rahim, kecuali Rasulullah Muhammad Saw. Hal ini sesuai dengan firman Allah SWT dalam surah al-Taubah (9) ayat 128:

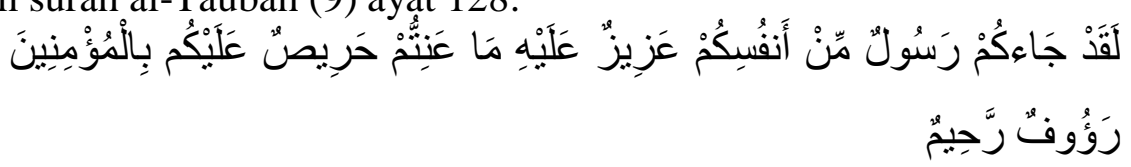

Demi sesungguhnya telah datang kepada kamu seorang rasul dari diri kamu sendiri, berat terasa olehnya apa yang telah menderitakan kamu; sangat menginginkan (kebaikan) bagi kamu; terhadap orang-orang mukmin rauf dan rahim/amat kasih lagi penyayang (QS. al-Taubah/9: 128).

Ketika menafsirkan ayat al-Taubah ini, penulis mengemukakan bahwa: "kalaulah beliau bersikap tegas, atau ada tuntutan yang sepintas terlihat atau terasa berat, maka itu adalah untuk kemaslahatan umatnya jua. Sebenarnya hati beliau lebih dahulu teriris-iris melihat ada kesulitan atau penderitaan yang dialami manusia".

Pembentukan kepribadian nabi Muhammad Saw., sehingga menjadikan sikap, ucapan, perbuatan, bahkan seluruh totalitas beliau adalah rahmat, bertujuan mempersamakan totalitas beliau dengan ajaran yang beliau sampaikan, karena ajaran beliau pun adalah rahmat menyeluruh, menyatu antara ajaran dan penyampaian ajaran, menyatu antara risalah dan rasul, dan karena itu pula Rasulullah Saw., adalah penjelmaan kongkrit dari akhlak al-Qur'an sebagaimana dilukiskan oleh Aisyah ra (HR. Ahmad ibn Hanbal). 
Kata al-'alamin maknanya dalam arti kumpulan jenis makhluk Allah yang hidup, semuanya memperoleh rahmat dengan kehadiran nabi Muhammad Saw. Dengan rahmat itu terpenuhilah hajat batin manusia untuk meraih ketenangan, ketentraman, serta pengakuan atas wujud, hak, bakat, dan fitrahnya.

Jangankan manusia, binatang dan tumbuh-tumbuhan pun memperoleh rahmatnya. Sebelum Eropa mengenal organisasi pencinta binatang, Rasulullah Saw., telah mengajarkan perlunya mengasihi binatang, seperti yang tergambar dalam perintah mengasah pisau terlebih dahulu sebelum menggunakanya menyembelih. Selain mengasihi binatang, ajaran rahmat yang Rasulullah Saw., tunjukkan adalah beliau melarang keras memetik bunga sebelum mekar atau memetik buah sebelum matang, karena tugas manusia adalah mengantar semua makhluk menuju tujuan penciptaannya. Bunga diciptakan antara lain agar mekar sehingga lebah datang menghisap sarinya, dan mata menjadi senang memandangnya. Bahkan bendabenda tak bernyawa pun mendapat rahmat dan kasih sayang beliau.

\section{Implikasi QS. al-Anbiya' Ayat 107 dalam Pendidikan}

Hal yang diinginkan oleh ayat ini adalah umat Islam menjadi rahmat bagi semesta alam. Agar supaya pesan yang disampaikan oleh Qs. al-Anbiya' (21) ayat 107 bisa sampai dan dipahami secara utuh dan komprehensif oleh umat Islam/para peserta didik, maka peran guru atau pendidik sangat menentukan. Apabila terjadi kesalahan dalam pemahaman terhadap suatu ayat, maka akibat yang akan ditimbulkannya adalah akan melahirkan manusia yang atoleran, esklusif, keras dan beringas, seperti yang tergambar dalam pendahuluan. Hal ini tentu saja bukan tujuan Islam, khususnya tujuan pendidikan Islam. Oleh karena itu, berhasil atau tidaknya suatu proses pendidikan, terletak pada diri sosok guru/tenaga pendidiknya.

Dalam Islam, guru merupakan profesi yang sangat mulia, karena pendidikan adalah salah satu tema sentral Islam. Nabi Muhammad Saw., sendiri sering disebut sebagai "pendidik kemanusiaan atau educator of mindkind (Lihat Azyumardi Azra, 1999: 167, Jamali Sahrodi, 2005: 19-20).

Bagi Islam, guru haruslah bukan hanya tenaga pengajar, tetapi sekaligus adalah pendidik. Karena itu, dalam Islam, seseorang dapat menjadi guru bukan hanya karena ia telah memenuhi kualifikasi keilmuan dan akademis saja, tetapi lebih penting lagi ia harus terpuji akhlaknya. Dengan demikian, seorang guru bukan hanya mengajarkan ilmu-ilmu pengetahuan saja, tetapi lebih penting pula membentuk 
watak dan pribadi anak didiknya dengan akhlak dan ajaran-ajaran Islam.

Hasan Langgulung seorang pakar pendidikan Islam menyatakan bahwa pendidikan itu bukan hanya transfer of knowledge atau transfer ilmu pengetahuan, tetapi transfer of value atau transfer nilai/budaya (Hasan Langgulung, 1995: 7). Dengan demikian, pendidikan lebih dari sekedar pengajaran. Pengajaran lebih menekankan pada transfer ilmu, sementara pendidikan lebih menekankan pada transformasi nilai dan pembentukan kepribadian dengan segala aspeknya.

Celakanya, pada saat sekarang ini, fenomena yang ada dalam pendidikan kita, keberhasilan pendidikan itu diukur dengan sejauhmana siswa dalam penguasaan materi pelajaran belaka. Hal ini didukung oleh kebijakan pemerintah yang menerapkan kebijakan Ujian Nasional (UN) yang disandarkan pada evaluasi pada satu aspek saja, yakni aspek kognitif, sedangkan aspek afektif dan psikomotorik diabaikan, terlebih lagi aspek nilai atau agama.

Padahal kalau kita tinjau dengan konsep UNESCO dalam pendidikan, maka keberhasilan pendidikan itu diukur dari hasil 4 pilar pengalaman belajar anak, yakni: (1) belajar mengetahui (learning to know), (2) belajar berbuat (learning to do), (3) belajar hidup bersama (learning to live togheter), dan (4) belajar menjadi seseorang (learning to be). Keseimbangan antara 4 pilar pendidikan itu dapat memberikan wawasan, tindakan, kebersamaan, dan pembentukan pribadi menjadi seimbang yang lebih membawa jalan peserta didik menuju perkembangan peradabannya (Djohar, 2000: 118).

Untuk itu agar pendidikan kita bisa sejalan dan selaras dengan firman Allah Qs. al-Anbiya' (21) ayat 107, penulis menawarkan solusi sebagai berikut:

\section{Perubahan Paradigma dari Mengajar Menjadi Mendidik}

Hendaknya guru ketika mengajar memegang paradigma bahwa dirinya adalah merupakan pendidik, bukan pengajar. Kalau seandainya masih berparadigma sebagai pengajar, maka dia akan melaksakan tugasnya hanya sekedar menyelesaikan materi yang ada saja. Guru akan merasa gugur kewajibannya setelah dia menyampaikan semua materi pelajaran. Adapun tentang peserta didik itu mau berubah atau tidak perilakunya itu bukan tanggungjawabnya. Dengan memegang paradigma itu, maka ada suatu kesalahan yang fatal dalam dunia pendidikan kita. Sehingga sangat wajar apabila masyarakat menuding pendidikan agama Islam di sekolah dianggap gagal, karena seringnya muncul fenomena tawuran antar pelajar, perilaku seks bebas, 
mengkonsumsi obat-obat terlarang (NAPZA), dan perilaku-perilaku menyimpang lainnya.

Hal di atas tentu akan dapat diminimalisir, apabila guru memegang paradigma mendidik bukan mengajar. Karena dalam konsep Islam, guru itu bukan hanya tenaga pengajar, tetapi sekaligus adalah pendidik. Karena itu, dalam Islam, seseorang dapat menjadi guru bukan hanya karena ia telah memenuhi kualifikasi keilmuan dan akademis saja, tetapi lebih penting lagi ia harus terpuji akhlaknya. Dengan demikian, seorang guru bukan hanya mengajarkan ilmu-ilmu pengetahuan saja, tetapi lebih penting pula membentuk watak dan pribadi anak didiknya dengan akhlak dan ajaran-ajaran Islam.

\section{Pendidikan Islam itu Humanis dan Anti Kekerasan}

Inti ajaran Islam adalah agama rahmatan lil'alamin. Untuk itu dalam implementasinya, pendidikan Islam itu harus bersifat humanis dan antikekerasan.

Menurut Paulo Freire, sudah menjadi pengetahuan kita bersama bahwa pendidikan yang humanis itu memberikan kebebasan yang luas untuk berpikir kritis (Paulo Freire, 2002: 195. Gagasan Paulo Freire adalah bagaimana manusia bisa terbebaskan dari kekuasaan pemerintah yang absolut. Gagasan Paulo Freire itu sudah dilaksanakan 14 abad yang lalu oleh nabi Muhammad Saw., yang menentang keras adanya perbudakan. Karena perbudakan itu sangat bertentangan dengan prinsip dasar kemanusiaan yang humanis. Oleh karena itu, nabi Muhammad Saw., itu sangat humanis sekali. Pernyataan ini juga pernah dilontarkan oleh Fazlur Rahman bahwa ajaran Muhammad Saw., tentang monotheime yang diserukan Muhammad Saw., sejak awal mula sekali adalah terkait dengan suatu humanisme dan rasa keadilan sosial (Fazlur Rahman, 2000).

Untuk bisa mencapai pendidikan yang humanis dan antikekerasan, maka dalam aktivitas mendidik atau menumbuhkan hendaknya dilakukan dengan bijaksana sehingga efektivitas dan efisiensinya jelas. Kekerasan tidak boleh menyertai dalam proses mendidik, karena kekerasan menunjukkan pemaksaan (Sumedi, 2010: 80). Apabila seorang peserta didik salah atau tidak bisa, maka tidak boleh sorang guru menghukumnya dalam bentuk kekerasan fisik. Karena hal itu bertentangan dengan hak asasi manusia (HAM) dan inti dari ajaran Islam: rahmatan lil'alamin.

Dalam proses pembelajarannya, pendidikan humanis dan antikekerasan dapat terwujud apabila guru dalam menyampaikan materi yang disampaikannya harus diikuti dengan metode dialog untuk menghindari kesalahpahaman yang mungkin terjadi pada diri peserta 
didik sehingga tidak menimbulkan ekses negatif bagi umat Islam dan juga bagi agama lain, karena Islam dikenal sebagai agama rahmatan lil'alamin (Moh. Roqib, 2009: 181). Dan itu harus dibuktikan oleh setiap Muslim dalam kehidupan sehari-hari.

\section{Mendidik Sikap Inklusif}

Pendidikan inklusif memberikan keberanian setiap insan untuk menerima perbedaan sekaligus kesiapan untuk membangun dunia ini secara lebih damai dan nyaman untuk dihuni secara bersama-sama. Dalam hubungan sesama dan antaragama perlu dikembangkan solidaritas bersama yang mampu menciptakan kerukunan antar pemeluk agama dan keyakinan. Jangan sampai terjadi lagi perusakan tempat ibadah di luar agama kita seperti yang terjadi di Temanggung.

Terlebih khusus lagi, kerukunan antarpemeluk agama Islam. Jangan sampai terjadi lagi orang Islam yang merusak tempat ibadah sesama umat Islam seperti terjadi di kabupaten Kuningan beberapa bulan yang lalu, ada orang yang "mengaku Islam", tapi merusak masjid jamaah Ahmadiyah Kuningan. Jangan sampai terjadi lagi pembantaian terhadap penganut Ahmadiyah seperti yang terjadi di Cikeusik Pandeglang.

Dengan pendidikan inklusif ini diharapkan dapat membentuk sikap dan perilaku umat Islam bisa saling menghormati, menghargai, dan toleransi terhadap perbedaan agama, suku, ras dan pendapat.

Last but not least, Rahmat itu memiliki 3 dimensi, yaitu: pertama; rasionalitas, kedua; peduli, dan ketiga; peradaban. Pertama; agama Islam adalah agama yang rasional. Apabila ada ajakan atau doktrin yang menyatakan bahwa "bidadari telah menunggu para mujahidin" dengan cara bom bunuh diri dengan mengebom tempattempat maksiat atau tempat-tempat milik non Muslim adalah merupakan tindakan yang konyol dan irrasional.

Kedua; ajaran Islam dengan konsepsi rahmatan lil'alamin memiliki konsekuensi logis untuk selalu peduli kepada orang yang memerlukan pertolongan atau bantuan. Apabila ada yang terkena musibah kecelakaan di jalan raya, ketika hendak menolong, maka tidak perlu ditanyakan lagi apa agama sampean? Islam apa Kristen? Islamnya NU atau Muhammadiyah? NU-nya PKB atau PPP? PKB-nya Gus Dur atau Muhaemin? Pertanyaan-pertanyaan tersebut tidak perlu, yang terpenting ketika ada orang yang terkena musibah, maka harus segera ditolong. Ini adalah merupakan bentuk kepedulian, karena menolong adalah inti ajaran Islam yang universal.

Ketiga; Agama Islam adalah agama peradaban. Rasulullah Saw di utus di muka bumi ini adalah untuk membangun peradaban. Hal ini 
dapat terlihat dari ajarannya dalam membebaskan perbudakan, menghargai perempuan, menghargai perbedaan agama, dan menjunjung tinggi ilmu pengetahuan.

\section{Penutup}

berikut:

Dari beberapa uraian di atas, dapat penulis simpulkan sebagai

1. Dalam al-Qur'an surat al-Anbiya' (21) ayat 107 dinyatakan bahwa Islam adalah agama yang membawa rahmat bagi semesta alam. Dari ayat tersebut penulis simpulkan bahwa nabi Muhammad Saw., merupakan rahmat bagi seluruh umat manusia, baik yang beriman kepadanya maupun yang tidak beriman dan bahwasanya nabi Muhammad Saw., itu diutus sebagai rahmat bagi seluruh alam semesta.

2. Isi kandungan Qs. al-Anbiya' (21) ayat 107 memiliki implikasi dalam dunia pendidikan. Implikasi yang dapat penulis tawarkan agar supaya pendidikan kita bisa melahirkan peserta didik yang sesuai dan selaras dengan ayat tersebut adalah: pertama; perubahan paradigma guru dari mengajar menjadi mendidik. Kedua; pendidikan Islam itu humanis dan antikekerasan. Ketiga; mendidik sikap inklusif.

3. Rahmat itu memiliki 3 dimensi, yaitu: rasionalitas, peduli, dan peradaban. Pertama, agama Islam adalah agama yang rasional. Apabila ada ajakan atau doktrin yang menyatakan bahwa "bidadari telah menunggu para mujahidin" dengan cara bom bunuh diri dengan mengebom tempat-tempat maksiat atau tempat-tempat milik non Muslim adalah merupakan tindakan yang konyol dan irrasional. Kedua, ajaran Islam dengan konsepsi rahmatan lil'alamin memiliki konsekuensi logis untuk selalu peduli kepada orang yang memerlukan pertolongan atau bantuan. Apabila ada yang terkena musibah kecelakaan di jalan raya, ketika hendak menolong, maka tidak perlu ditanyakan lagi apa agama sampean? Islam apa Kristen? Islamnya NU atau Muhammadiyah? NU-nya PKB atau PPP? PKBnya Gus Dur atau Muhaemin? Pertanyaan-pertanyaan tersebut tidak perlu, yang terpenting ketika ada orang yang terkena musibah, maka harus segera ditolong. Ini adalah merupakan bentuk kepedulian, karena menolong adalah inti ajaran Islam yang universal.

Ketiga, Agama Islam adalah agama peradaban. Rasulullah Saw di utus di muka bumi ini adalah untuk membangun peradaban. Hal ini dapat terlihat dari ajarannya dalam membebaskan perbudakan, menghargai perempuan, menghargai perbedaan agama, dan menjunjung tinggi ilmu pengetahuan. Jadi fenomena perusakan 
masjid, gereja, dan pembantaian penganut jama'ah Ahmadiyah adalah bukan merupakan tindakan orang Islam, karena perbuatan itu dilakukan oleh orang yang tidak beradab.

\section{Daftar Pustaka}

Azra, Azyumardi. Esei-esei Intelektual Muslim dan Pendidikan Islam, Jakarta: Logos Wacana Ilmu, 1999.

Djohar. "Praksis Pendidikan Berwawasan Ekologi", dalam Menggagas Paradigma Baru Pendidikan: Demokratisasi, Otonomi, Civil Society, dan Globalisasi, (ed.,) Sindhunata, Yogyakarta: Kanisius, 2000.

Freire, Paulo. Politik Pendidikan: Kebudayaan, Kekuasaan dan Pembebasan, Yogyakarta: Pustaka Pelajar, 2002.

Hamka. Tafsir al-Azhar juz 17, Jakarta: Pustaka Panjimas, 2001.

Langgulung, Hasan. Asas-Asas Pendidikan Islam, Jakarta: Pustaka alHusna, 1995.

Madjid, Nurcholish. Islam Doktrin dan Peradaban, Jakarta: Paramadina, 2000.

Al-Maraghi, Ahmad Musthofha. Tafsir al-Maraghi jilid 17, Semarang: Toha Putra, 1993.

Moh. Roqib, Ilmu Pendidikan Islam: Pengembangan Pendidikan Integratif di Sekolah, Keluarga dan Masyarakat, Yogyakarta: LKis, 2009.

Nasution, Harun. Islam Rasional: Gagasan dan Pemikiran, Bandung: Mizan, 1995.

Quthb, Sayyid. Tafsir fi Zhilalil Qur'an jilid 8, Jakarta: Gema Insani Press, 2004.

Rahman, Fazlur. Islam, terjemahan Mohammad Ahsin, Bandung: Pustaka, 2000.

Sahrodi, Jamali. Membedah Nalar Pendidikan Islam, Cirebon: STAIN Cirebon Press, 2005.

Al-Shiddieqy, Teungku Muhammad Hasbi. Tafsir al-Qur'anul Majid an-Nuur jilid 3, (Semarang: Pustaka Rizki Putra, 2000).

Shihab, M. Quraish. Tafsir al-Misbah volume 8, Jakarta: Lentera Hati, 2006.

----. Wawasan Al-Qur'an: Tafsir Maudhu'i Atas Pelbagai Persoalan Umat, Bandung: Mizan, 1996.

Sumedi dalam, "Kritisisme Hikmah: Ke Arah Epistemologi Pendidikan Islam Humanis", dalam Antologi Pendidikan Islam, Nizar Ali dan Sumedi (ed.), Yogyakarta: Idea Press, 2010.

Tim Tafsir UII, Al-Qur'an dan Tafsirnya jilid VI, Yogyakarta: PT. Dana Bakti Wakaf, 1995. 